\title{
Fever-induced QTc prolongation and ventricular arrhythmias in individuals with type 2 congenital long QT syndrome
}

Ahmad S. Amin, ${ }^{1,2}$ Lucas J. Herfst, ${ }^{3,4}$ Brian P. Delisle, ${ }^{2}$ Christine A. Klemens, ${ }^{2}$ Martin B. Rook, ${ }^{3}$ Connie R. Bezzina, ${ }^{1}$ Heather A.S. Underkofler, ${ }^{2}$ Katherine M. Holzem, ${ }^{2}$ Jan M. Ruijter, ${ }^{1}$ Hanno L. Tan, ${ }^{1}$ Craig T. January, ${ }^{2}$ and Arthur A.M. Wilde ${ }^{1}$

${ }^{1}$ Heart Failure Research Center, Academic Medical Centre, University of Amsterdam, Amsterdam, The Netherlands. 2Departments of Medicine and Physiology, Cellular and Molecular Arrhythmia Research Program, University of Wisconsin, Madison, Wisconsin, USA. ${ }^{3}$ Department of Medical Physiology, Division of Heart and Lungs, University Medical Centre Utrecht, Utrecht, The Netherlands. ${ }^{4}$ Bernstein Centre for Computational Neuroscience, Humboldt University of Berlin, Berlin, Germany.

\begin{abstract}
Type 2 congenital long QT syndrome (LQT-2) is linked to mutations in the human ether a-go-go-related gene $(H E R G)$ and is characterized by rate-corrected $Q T$ interval $(\mathrm{QTc})$ prolongation, ventricular arrhythmias, syncope, and sudden death. Recognized triggers of these cardiac events include emotional and acoustic stimuli. Here we investigated the repeated occurrence of fever-induced polymorphic ventricular tachycardia and ventricular fibrillation in 2 LQT-2 patients with A558P missense mutation in HERG. ECG analysis showed increased QTc with fever in both patients. WT, A558P, and WT+A558P HERG were expressed heterologously in HEK293 cells and were studied using biochemical and electrophysiological techniques. A558P proteins showed a trafficking-deficient phenotype. WT + A558P coexpression caused a dominant-negative effect, selectively accelerated the rate of channel inactivation, and reduced the temperature-dependent increase in the WT current. Thus, the WT+A558P current did not increase to the same extent as the WT current, leading to larger current density differences at higher temperatures. A similar temperature-dependent phenotype was seen for coexpression of the trafficking-deficient LQT-2 F640V mutation. We postulate that the weak increase in the HERG current density in WT-mutant coassembled channels contributes to the development of QTc prolongation and arrhythmias at febrile temperatures and suggest that fever is a potential trigger of life-threatening arrhythmias in LQT-2 patients.
\end{abstract}

\section{Introduction}

Congenital long QT syndrome (LQTS) is a genetic disease characterized by delayed cardiac repolarization and prolongation of the QT interval on the ECG. LQTS displays an autosomal dominant (Romano-Ward syndrome) or recessive (Jervell LangeNielsen syndrome) inheritance pattern. To date, 10 types of LQTS are known, and each type is linked to mutations in a gene encoding a cardiac ion channel or accessory or regulatory subunits (1). Mutations in the human ether a-go-go-related gene (HERG) are responsible for the type 2 LQTS (LQT-2) (2). HERG encodes the $\alpha$ subunit for the rapidly activating, delayed rectifier $\mathrm{K}^{+}$current $\left(\mathrm{I}_{\mathrm{Kr}}\right) . \mathrm{I}_{\mathrm{Kr}}$, an outward $\mathrm{K}^{+}$current during phases 2 and 3 of the cardiac action potential, plays an important role in cardiac repolarization $(3,4)$.

Nearly 300 HERG mutations are linked to LQT-2, and a small number of these mutations have been heterologously expressed to study the mechanism by which they cause LQT-2. HERG mutations are found to reduce $\mathrm{I}_{\mathrm{Kr}}$, mostly due to deficient trafficking of incorrectly folded mutant channel proteins from the ER to the cell membrane $(5,6)$. The incorrectly folded mutant

Nonstandard abbreviations used: BrS, Brugada syndrome; HERG, human ether-ago-go-related gene; HERG, HERG-encoding channel protein; $\mathrm{I}_{\mathrm{Kr}}$, rapidly activating, delayed rectifier $\mathrm{K}^{+}$current; $\mathrm{I}_{\text {tail, }}$ HERG tail current; LQT-2, type 2 LQTS; LQTS, congenital long QT syndrome; QTc, rate-corrected QT interval; TdP, torsades de pointes; VF, ventricular fibrillation.

Conflict of interest: The authors have declared that no conflict of interest exists. Citation for this article: J. Clin. Invest. 118:2552-2561 (2008). doi:10.1172/JCI35337. proteins are retained in the ER through the actions of quality control systems and kept from reaching the cell membrane to form HERG channels (7). Other mechanisms by which HERG mutations reduce $\mathrm{I}_{\mathrm{Kr}}$ in LQT-2 include abnormal HERG protein synthesis or altered gating or permeation properties of mutant HERG channels in the cell membrane (7). Regardless of the underlying mechanism, $\mathrm{I}_{\mathrm{Kr}}$ reduction results in delayed cardiac repolarization and prolongation of the action potential duration, which is represented as prolongation of the QT interval on the ECG (8).

LQTS is associated with polymorphic ventricular tachycardia (torsades de pointes; TdP) and ventricular fibrillation (VF), leading to syncope, seizure, and sudden death. Genotype-phenotype correlation studies have revealed gene-specific triggers that may precipitate such cardiac events in LQTS (9). Auditory stimuli and emotional stress are well-known triggers of cardiac events in LQT-2 patients with HERG mutations $(9,10)$. Previously, fever (body temperature elevated above $38^{\circ} \mathrm{C}$ ) (11) has not been recognized as a trigger of cardiac events in LQTS. In this study, we describe 2 closely related, adult LQT-2 patients with the A558P HERG missense mutation, who suffered from fever-induced QT prolongation, TdP, and VF. We hypothesized that the A558P mutation affects the HERG channel function in a temperaturedependent manner. To test this hypothesis, we analyzed the effects of the A558P mutation on HERG channel protein expression and studied the biophysical properties of mutant channel currents at $23^{\circ} \mathrm{C}, 35^{\circ} \mathrm{C}$, and $40^{\circ} \mathrm{C}$. 


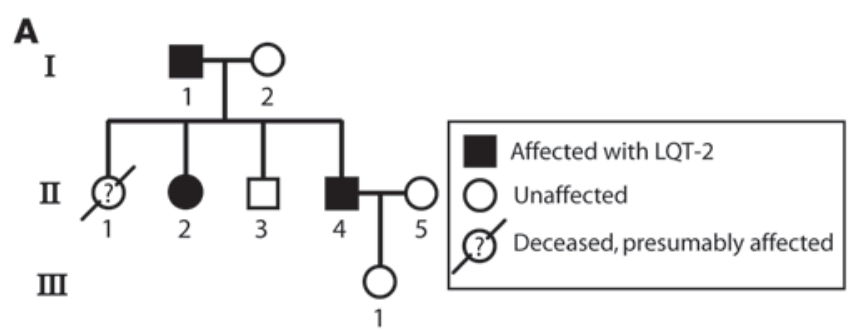

B
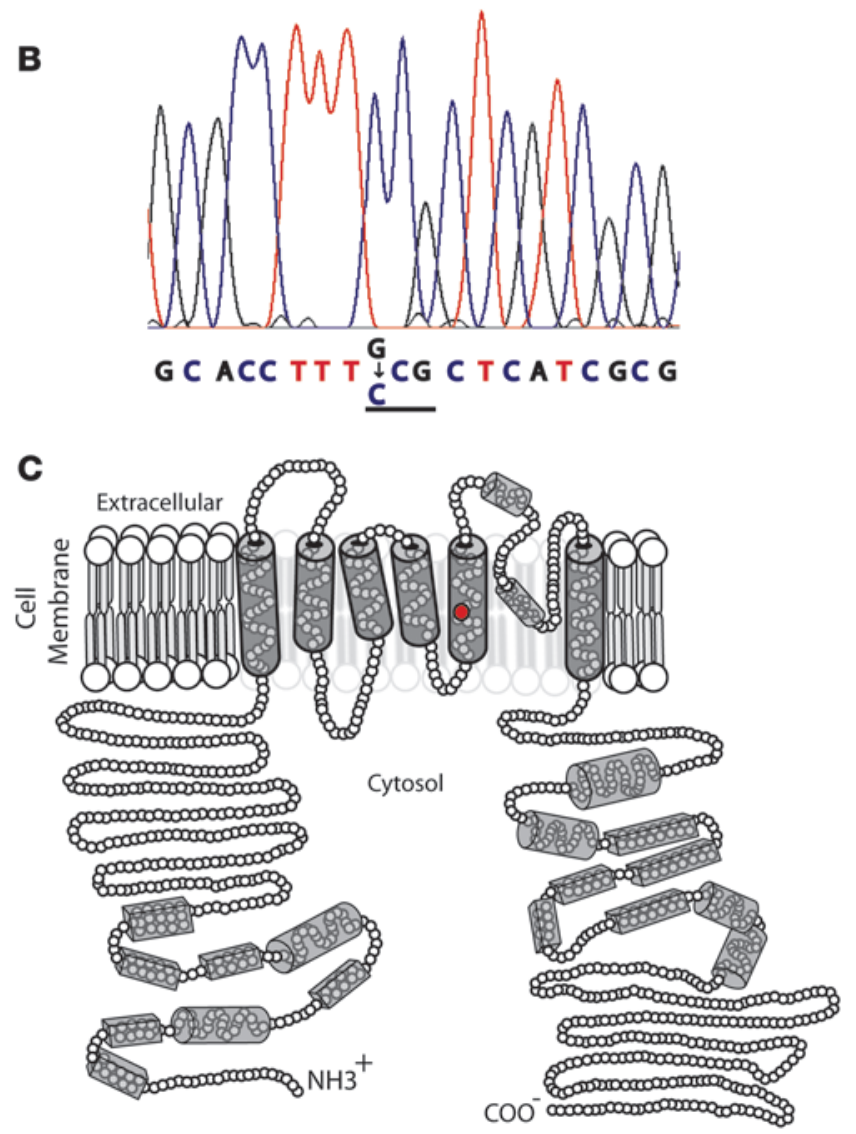

\section{Results}

Genetic analysis. We previously described the A558P HERG mutation in a genetic screening study (12). The index patient was a 22-year-old female of mixed European descent (II-1) who died suddenly upon arousal from sleep by an alarm clock (Figure 1A). Mutation analysis of HERG in 15 family members from 3 consecutive generations identified 3 heterozygous carriers of a missense mutation ( $\mathrm{G}$ to $\mathrm{C}$ nucleotide change, at position 1,672 of HERG; Figure $1 \mathrm{~B}$ ), substituting the amino acid alanine (A) for proline (P) at codon 558 of the transmembrane S5 segment of the HERG channel protein (Figure 1C). Linkage analysis excluded a role for the other 2 most common genetic loci of LQTS, type 1 (KCNQ1 gene) and type 3 (SCN5A gene). Generation I consisted of 10 siblings, but only 1 patient (I-1) carried the A558P mutation (12). This finding suggested that this mutation had occurred de novo in patient I-1. Patients I- 1 and II-4 are reported in this study. To date, patient II- 2 remains asymptomatic with $\beta$-blocker treatment, and ECGs during fever have never been obtained.

Patient I-1. Patient I-1, a 68-year-old male, was diagnosed with Romano-Ward syndrome in 1984 and was treated with the $\beta$-block-

\section{Figure 1}

Genetic and sequence analysis of the A558P HERG mutation. (A) Pedigree of the family with the A558P HERG mutation. Mutation analysis in 10 siblings of generation I identified only 1 patient (I-1) as carrier of the A558P mutation (see ref. 12). (B) DNA sequence analysis displaying the $G$ to $C$ substitution at position 1,672 of exon 7. (C) Cartoon of a single subunit of the functional HERG channel, illustrating its 6 transmembrane segments and the location of the A558P mutation as a red dot in the S5 segment. The pore region is located between the S5 and S6 segments. The cylinders and the bars represent putative $\alpha$ helices and $\beta$ sheets, respectively. Four such subunits coassemble in a tetrameric structure to form 1 functional HERG channel in the cell membrane.

er alprenolol (100 mg twice daily). He experienced syncope during a Second World War bombardment in 1945. Patient I-1 presented to the emergency department because of 2 episodes of syncope accompanied by fever, cough, and a sore throat since 1 day before admission. Physical examination revealed fever of $39.7^{\circ} \mathrm{C}$ without localizing symptoms. Blood tests, urine analysis, chest roentgenogram, and echocardiography were normal. Figure 2A shows lead II of the ECG on admission, with sinus rhythm (85 bpm), normal conduction intervals, and a prolonged rate-corrected QT interval (QTc) duration of $540 \mathrm{~ms}$. His prior baseline ECG showed no abnormalities except for a prolonged QTc of $504 \mathrm{~ms}$ (data not shown). Shortly after admission, 4 episodes of TdP and VF were observed (Figure 2B), occasionally requiring defibrillation (13). Treatment with alprenolol was continued, and immediate treatment with antipyretics (acetaminophen), oral broad-spectrum antibiotics (amoxicillin/clavulanate), and intravenous $\mathrm{K}^{+}$and $\mathrm{Mg}^{2+}$ was initiated. The body temperature normalized 8 days after admission. Repeated blood cultures were negative, and no cause for the fever was found. The patient was discharged, and advised to return immediately if fever recurred. Four months later, he returned to a different hospital with fever of $40^{\circ} \mathrm{C}$ due to a urinary tract infection. During this episode, he experienced VF, requiring defibrillation, and a cardioverter-defibrillator (ICD) was implanted.

Patient II-4. Patient II-4, a 41-year-old male and the son of patient I-1, was admitted after an episode of syncope with TdP and VF documented by the paramedics. An hour before the syncope, he had experienced rigor. This patient had also been diagnosed with Romano-Ward syndrome in 1984 . He had been asymptomatic on $\beta$-blocker treatment (metoprolol, $100 \mathrm{mg}$ once daily), with a prior baseline ECG showing a prolonged QTc of $480 \mathrm{~ms}$ and no further abnormalities. Physical examination after resuscitation revealed fever of $38.5^{\circ} \mathrm{C}$ and an infected wound on digit III of the right foot. Laboratory tests showed leukocytosis $\left(16,700 / \mathrm{mm}^{3}\right)$. His ECG on admission showed normal sinus rhythm ( $64 \mathrm{bpm})$, normal conduction intervals, and a prolonged QTc of $545 \mathrm{~ms}$. Flucloxacillin treatment normalized the body temperature 2 days after admission, and the foot wound healed. An ICD was implanted.

QTc analysis. QTc durations during 2 febrile episodes and following resumption of normothermia (body temperature below $38^{\circ} \mathrm{C}$ ) (11) were performed on patients I- 1 and II-4. Body temperature during each ECG recording was assessed by tympanic membrane (ear) temperature measurements, along with measurements of serum $\mathrm{K}^{+}$levels within 1 hour (Figure 2C, left panel). Repeated ECGs of patient I-1 showed QTc lengthening at higher body temperatures $(r=0.78 ; P<0.05)$. Repeated ECGs of patient II-4 revealed a similar pattern of temperature-dependent changes in QTc $(r=0.93 ; P<0.01)$. The linear fits for both patients were nei- 
A

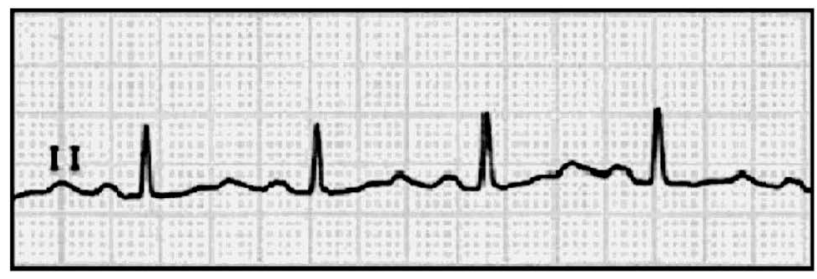

B
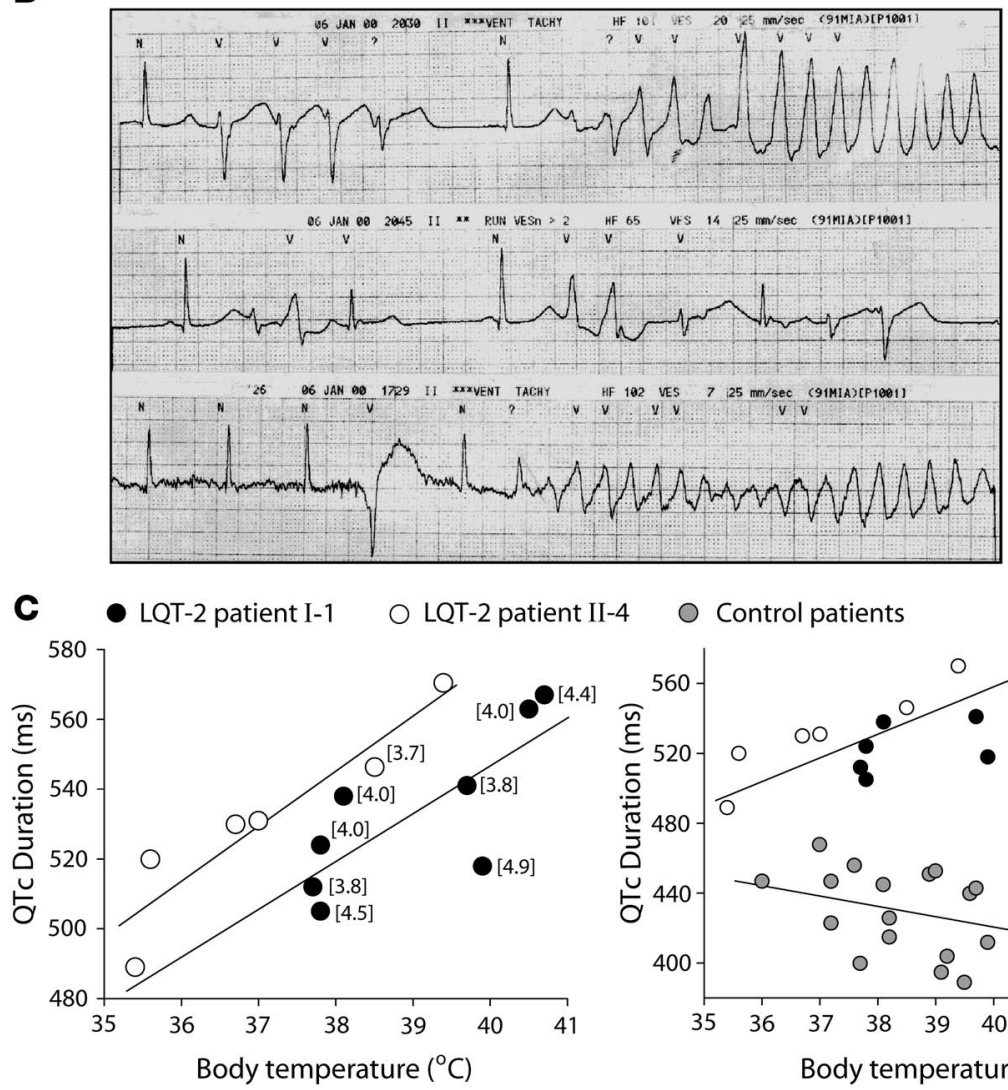

Figure 2

Fever-associated QTc prolongation and TdP. (A) Lead II of the ECG of patient I-1 on admission, showing an abnormal repolarization profile and prolonged QTc duration of $540 \mathrm{~ms}$ (body temperature, $39.7^{\circ} \mathrm{C}$; standard calibration, $25 \mathrm{~mm} / \mathrm{sec}$ and $10 \mathrm{~mm} / \mathrm{mV}$ ). (B) Two episodes of TdP in patient I-1 during fever. Both episodes are pause-dependent, as is typical for LQT-2 (13). The middle trace shows the pause-dependent onset of multiform ectopic beats (lead II). (C) The left panel shows QTc durations in LQT-2 patients I-1 and II-4 in relation to body temperature. Numbers next to the circles indicate serum $\mathrm{K}^{+}$levels $(\mathrm{mmol} / \mathrm{l})$. Solid lines represent linear fits. In both patients, QTc durations increased with rising body temperature. The slopes of the fits in patient I-1 $\left(14 \mathrm{~ms} /{ }^{\circ} \mathrm{C}\right)$ and patient II-4 $\left(16 \mathrm{~ms} /{ }^{\circ} \mathrm{C}\right)$ are not significantly different. The right panel shows QTc durations in LQT-2 patients compared with control patients in relation to body temperature. Solid lines represent the regression line through both groups based on the common slopes. The common slope of the fit through the LQT-2 patients $\left(15 \mathrm{~ms} /{ }^{\circ} \mathrm{C}\right)$ differs significantly from that of control patients $\left(-6 \mathrm{~ms} /{ }^{\circ} \mathrm{C}\right)$. ther different ( $P=0.72$ for intercepts; $P=0.73$ for slopes) nor was the location of the fits when plotted with a common slope (covariance analysis, $P=0.64$ ). This justified representation of the relation between QTc and body temperature for both patients with a common slope (Figure 2C, right panel). Previously, QT shortening had been reported during hyperthermia in patients without LQTS (14). To study the relation between body temperature and cardiac repolarization in patients without LQTS, QTc durations during fever and following resumption of normothermia were analyzed from 9 control patients (average age $48.9 \pm 6.5$ years) who were admitted for the treatment of a febrile episode (Figure 2C, right panel). In control patients, the average body temperature decreased from $39.6 \pm 0.3^{\circ} \mathrm{C}$ during fever to $37.5 \pm 0.3^{\circ} \mathrm{C}$ after recovery. QTc duration increased from $422 \pm 9 \mathrm{~ms}$ during fever to $436 \pm 6 \mathrm{~ms}$ after recovery. Thus, QTc duration in both LQT-2 patients increased significantly with rising temperature $\left(15 \mathrm{~ms} /{ }^{\circ} \mathrm{C} ; P<0.001\right)$ but decreased significantly in control patients $\left(-6 \mathrm{~ms} /{ }^{\circ} \mathrm{C} ; P<0.01\right)$.

A558P HERG expression. HERG mutations generally lead to deficient trafficking of incorrectly folded mutant channel proteins from the ER to the cell membrane $(5,6)$. To test whether the A558P mutation also leads to deficient trafficking of HERG proteins, western blot analysis was performed in HEK293 cells, which were transiently transfected with HERG cDNA to express WT or A558P HERG channels. Cells expressing WT HERG showed 2 separate protein bands on western blot, representing normal intracellular processing of the channel proteins (Figure 3A). The lower band (135-kDa molecular weight) represents immature core-glycosylated HERG proteins located in the ER, and the upper band (155 kDa) represents mature complexly glycosylated channel proteins located mostly in the cell membrane (15). This is characteristic for WT HERG proteins that traffic from the ER to the cell membrane through the Golgi apparatus, where they undergo complex glycosylation (7). In contrast, cells expressing A558P HERG exhibited only the lower immature band, characteristic for trafficking-deficient mutant HERG proteins that are retained in the ER, and failed to undergo complex glycosylation in the Golgi apparatus.

To confirm loss of HERG current with the A558P mutation, HERG tail currents ( $\left.\mathrm{I}_{\text {tail }}\right)$ were measured from HEK293 cells expressing WT or A558P channels using the patch-clamp technique. The cells were depolarized from a holding potential of $-80 \mathrm{mV}$ to $20 \mathrm{mV}$ for 5 seconds, followed by a hyperpolarizing step to $-120 \mathrm{mV}$ for 3 seconds to elicit large amplitude $\mathrm{I}_{\text {tail }}$ (Figure 3B). The depolarizing 
A
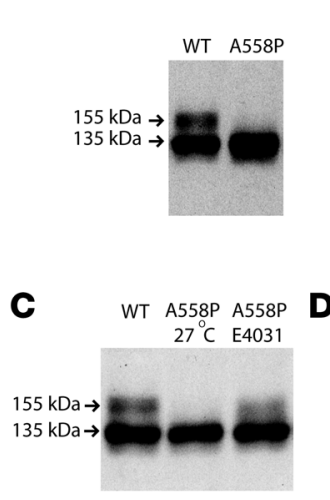

B

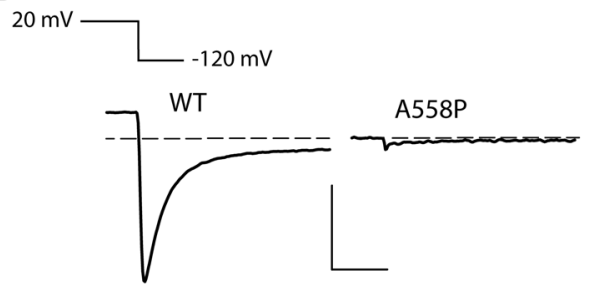

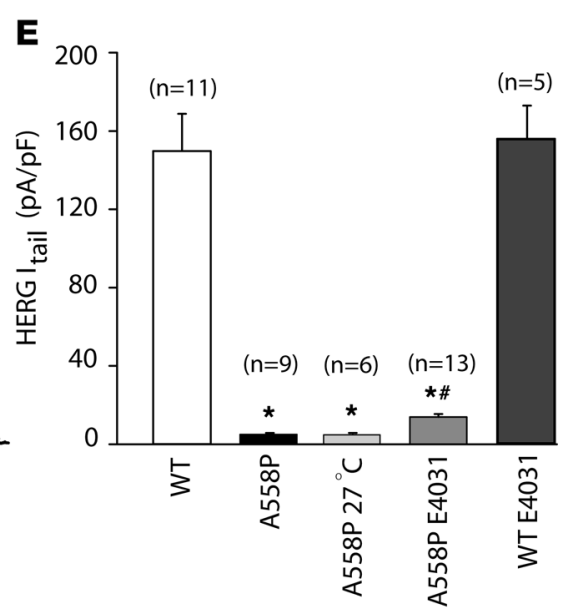

Figure 3

Trafficking-deficient phenotype of the A558P HERG mutation and attempts to correct the deficient trafficking. (A) Representative western blot of cells expressing WT and A558P HERG protein $(n=3)$. WT shows both mature complexly glycosylated $(155 \mathrm{kDa})$ and immature core-glycosylated $(135 \mathrm{kDa})$ protein bands. A558P displays only the immature band, representative for trafficking-deficient mutant HERG proteins. Cells were cultured at $37^{\circ} \mathrm{C}$. (B) Representative whole-cell I tail traces of WT or A558P-expressing cells. WT channels display typical $I_{\text {tail }}$, while only small amplitude $\mathrm{I}_{\text {tail }}$ could be recorded from cells expressing A558P. Cells were cultured at $37^{\circ} \mathrm{C}$. Scale bars: $1 \mathrm{nA}, 50 \mathrm{~ms}$. (C and D) Representative western blot $(n=3)$ and corresponding $\mathrm{I}_{\text {tail }}$ of WT and A558P following culture at $27^{\circ} \mathrm{C}$ or incubation for 24 hours with $10-\mu \mathrm{mol} / \mathrm{I} \mathrm{E}-4031$ (culture at $37^{\circ} \mathrm{C}$ ). Only incubation with E-4031 could minimally correct the deficient trafficking. Scale is as in B. (E) Average $I_{\text {tail }}$ densities. All $I_{\text {tail }}$ were measured at $23^{\circ} \mathrm{C}$. $\mathrm{n}$, number of cells. ${ }^{*} P<0.05$ compared with $\mathrm{WT} \mathrm{I}_{\text {tail }},{ }^{\#} P<0.05$ compared with A558P $I_{\text {tail. }}$.

step induced an outward HERG current that partially inactivated, and following the hyperpolarizing step, an inward $\mathrm{I}_{\text {tail }}$ was present as channels recovered quickly from inactivation and then gradually closed (16). $\mathrm{I}_{\text {tail }}$ measurements were consistent with the western blot data (Figure 3B). WT channels displayed typical I $\mathrm{I}_{\text {tail, }}$ while only small amplitude $\mathrm{I}_{\text {tail }}$ could be recorded from cells expressing A558P $(150 \pm 19$ and $5 \pm 1 \mathrm{pA} / \mathrm{pF}$, respectively; $P<0.001)$.

Reducing cell culture temperature or incubating cells with highaffinity HERG channel-blocking drugs (e.g., E-4031) are known to correct the deficient trafficking of most mutant HERG channel proteins to increase their expression on the cell membrane (5). Although the mechanism is incompletely understood, lower cell culture temperatures or binding of HERG channel-blocking drugs may stabilize intermediate folding states of the mutant proteins and promote their export out of the ER (7). However, trafficking of the A558P proteins could not be corrected by reducing the cell culture temperature to $27^{\circ} \mathrm{C}$ for 24 hours (Figure 3, C and D). Incubation of cells for 24 hours with $10-\mu \mathrm{mol} / 1 \mathrm{E}-4031$ resulted in the occurrence of a faint, mature protein band on western blot, suggesting limited correction of the trafficking-deficient phenotype of the A558P proteins. Incubation with E-4031, followed by drug washout for 1-2 hours, also led to a small increase of $\mathrm{I}_{\text {tail }}$ density $(14 \pm 1 \mathrm{pA} / \mathrm{pF}$ and $5 \pm 1 \mathrm{pA} / \mathrm{pF}$ for A558P cultured with or without E-4031, respectively; $P<0.05)$. To verify adequate washout of E-4031 (to exclude for the possibility that mutant currents were small because they were blocked by E-4031), we also incubated cells expressing WT HERG channels with 10- $\mu \mathrm{mol} / \mathrm{l}$ E-4031. No difference in $\mathrm{I}_{\text {tail }}$ density was seen between WT channels incubated with or without E-4031 (150 \pm 19 and $155 \pm 18 \mathrm{pA} / \mathrm{pF}$, respectively; Figure 3E), confirming adequate washout of E-4031. The $\mathrm{I}_{\text {tail }}$ densities are summarized in Figure 3E. Unfortunately, because the amplitudes were small, detailed biophysical analysis of A558P currents could not be performed.
Coexpression of WT and A558P. Since patients I-1 and II-4 are heterozygous for the A558P mutation, they carry both WT and mutant $H E R G$ alleles. Therefore, we determined whether the A558P mutant, HERG-encoded subunit proteins coassemble with WT subunit proteins, thereby disrupting the trafficking of WT proteins to the cell membrane (dominant-negative effect). For this, we coexpressed WT and A558P HERG in HEK293 cells. Western blot analy-

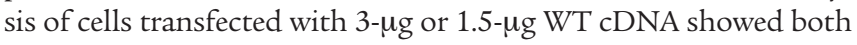
HERG protein bands (Figure 4A). In contrast, cells cotransfected with 1.5- $\mu \mathrm{g}$ WT and 1.5- $\mu \mathrm{g}$ A558P cDNA displayed the immature band with minimal or no mature protein band, indicating a dominantnegative effect of the A558P mutation on the trafficking of WT proteins. Itail densities of cells coexpressing WT + A558P $(52 \pm 12 \mathrm{pA} / \mathrm{pF})$ were significantly reduced $(P<0.01)$ compared with cells expressing 3- $\mu \mathrm{g}$ WT $(144 \pm 13 \mathrm{pA} / \mathrm{pF})$ or $1.5-\mu \mathrm{g}$ WT cDNA $(92 \pm 3 \mathrm{pA} / \mathrm{pF})$ (Figure 4, $\mathrm{B}$ and $\mathrm{C}$ ), confirming the dominant-negative effect.

The rate of HERG protein intracellular turnover, which includes its trafficking, is slow in heterologous expression (approximately 11 hours in HEK293 cells) (17) and may be even slower in cardiac myocytes (18). In contrast, the time course of clinical events was fast (i.e., arrhythmia in patient II- 4 occurred 1 hour after experiencing rigor). Therefore, altered expression of A558P HERG proteins during fever, leading to further disruption of WT protein trafficking, was not considered as a likely mechanism of fever-induced arrhythmia. However, in additional experiments, we cultured cells expressing A558P at $40^{\circ} \mathrm{C}$ to mimic fever. Similar to culture at $37^{\circ} \mathrm{C}$ and $27^{\circ} \mathrm{C}$, western blot analysis showed only an immature band (data not shown), indicating that the expression of A558P proteins is not changed at $40^{\circ} \mathrm{C}$.

Effect of temperature on WT and WT+A558P currents. Coexpression of WT HERG with A558P HERG showed a dominant-negative effect of the A558P mutation on the trafficking of WT HERG proteins, represented by loss of the mature band on western blot 
A

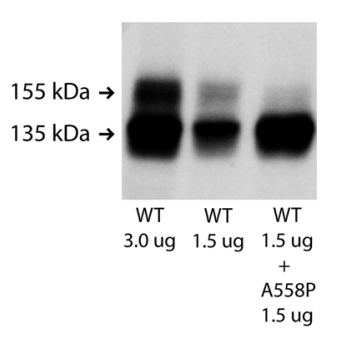

B

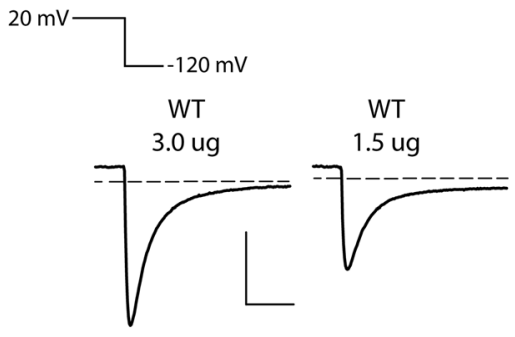

WT $1.5 \mathrm{ug}+$ A558P $1.5 \mathrm{ug}$

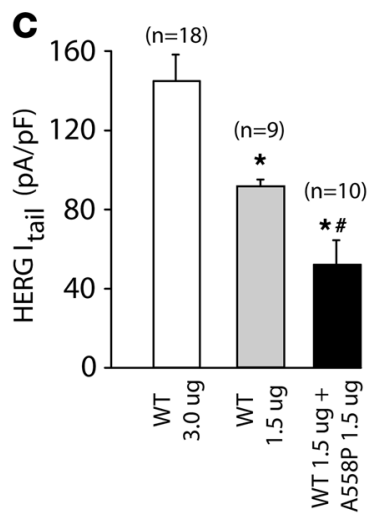

\section{Figure 4}

Dominant-negative effect of A558P HERG protein. (A) Representative western blot of cells transfected with 3- $\mu \mathrm{g}$ WT HERG cDNA, 1.5- $\mu \mathrm{g}$ WT cDNA plus 1.5- $\mu \mathrm{g}$ pCDNA3 vector, or 1.5- $\mu \mathrm{g}$ WT plus 1.5- $\mu \mathrm{g}$ A558P cDNA $(n=3)$. Cells transfected with 3- $\mu \mathrm{g}$ or $1.5-\mu \mathrm{g}$ WT cDNA show both immature and mature protein bands. Cells coexpressing WT+A558P show the immature band with minimal or no mature protein band. Cells were cultured at $37^{\circ} \mathrm{C}$. (B) Representative whole-cell Itail. Scale bars: $1 \mathrm{nA}, 50 \mathrm{~ms}$. (C) Average $\mathrm{I}_{\text {tail }}$ densities. Cells were cultured at $37^{\circ} \mathrm{C}$, and all $I_{\text {tail }}$ were measured at $23^{\circ} \mathrm{C} .{ }^{*} P<0.05$ compared with $3-\mu \mathrm{g} \mathrm{WT} \mathrm{I}_{\text {tail }}{ }^{\#} P<0.05$ compared with $1.5-\mu \mathrm{g} \mathrm{WT} \mathrm{I}_{\text {tail }}$.

and reduction of $\mathrm{I}_{\text {tail }}$ densities. Next, we studied whether the presence of the A558P mutant subunits also affected the function of the WT HERG channel and whether this effect was temperaturedependent. While the effect of temperature on protein trafficking was studied by altering the cell culture temperature, the effect of temperature on channel function was studied by altering the current recording temperature in the cell perfusion chamber. To study channel function, we measured gating properties (current density, activation, inactivation, recovery from inactivation, and deactivation) of WT and heteromeric WT+A558P mutant channels at $23^{\circ} \mathrm{C}, 35^{\circ} \mathrm{C}$, and $40^{\circ} \mathrm{C}$ recording temperature.

Current density. Figure 5A illustrates representative $\mathrm{I}_{\text {tail }}$ from WT and WT+A558P channels at different recording temperatures. Each temperature increase was achieved within 30 seconds. From $-80 \mathrm{mV}$, cells were depolarized to $20 \mathrm{mV}$ for 5 seconds and then repolarized to $-50 \mathrm{mV}$ for 3 seconds to measure $\mathrm{I}_{\text {tail }}$ (Figure $5 \mathrm{~A}$ ). As shown in Figure $5 \mathrm{~B}, \mathrm{I}_{\text {tail }}$ densities of both WT and WT $+\mathrm{A} 558 \mathrm{P}$ channels increased with rising temperatures $(89 \pm 7,150 \pm 11$, and $173 \pm 15 \mathrm{pA} / \mathrm{pF}$ for WT at $23^{\circ} \mathrm{C}, 35^{\circ} \mathrm{C}$, and $40^{\circ} \mathrm{C}$ versus $26 \pm 3,31 \pm 4$, and $36 \pm 5 \mathrm{pA} / \mathrm{pF}$ for $\mathrm{WT}+\mathrm{A} 558 \mathrm{P}$ at $23^{\circ} \mathrm{C}, 35^{\circ} \mathrm{C}$, and $40^{\circ} \mathrm{C}$, respectively; $P<0.005$ ). However, compared with WT channels, the temperature-dependent increase of $\mathrm{I}_{\text {tail }}$ density was significantly smaller for WT+A558P channels $\left(60 \pm 11\right.$ and $23 \pm 6 \mathrm{pA} / \mathrm{pF}$ for WT from $23^{\circ} \mathrm{C}$ to $35^{\circ} \mathrm{C}$ and $35^{\circ} \mathrm{C}$ to $40^{\circ} \mathrm{C}$ versus $7 \pm 1$ and $5 \pm 1 \mathrm{pA} / \mathrm{pF}$ for $\mathrm{WT}+\mathrm{A} 558 \mathrm{P}$ from $23^{\circ} \mathrm{C}$ to $35^{\circ} \mathrm{C}$ and $35^{\circ} \mathrm{C}$ to $40^{\circ} \mathrm{C}$, respectively; $\left.P<0.001\right)$. Thus, at each temperature, the heteromeric WT+A558P channel current was smaller than WT channel current, and the temperature-dependent increase in HERG current density for heteromeric channels was a small fraction of that found for WT channels. Taken together, these findings led to a larger difference in $\mathrm{I}_{\text {tail }}$ density between WT and WT+A558P channels at higher temperatures (Figure 5C).

To study whether other trafficking-deficient HERG mutations show a similar temperature-dependent phenotype to A558P, we studied the effect of temperature on $\mathrm{I}_{\text {tail }}$ density of WT HERG coexpressed with the F640V mutation (WT+F640V channel). F640V, first associated with LQT-2 in a genetic screening study (19), is a missense mutation, substituting the amino acid phenylalanine (F) for valine (V) at codon 640 of the transmembrane S6 segment of the HERG channel protein. We previously showed that, similar to A558P, (a) F640V homomeric channels have a trafficking-deficient phenotype; (b) their deficient trafficking is not correctable by culture at $27^{\circ} \mathrm{C}$; and (c) coexpression of F640V with WT HERG imposes a dominant-negative effect (5). As shown in Figure 5, B and $\mathrm{C}, \mathrm{I}_{\text {tail }}$ densities of cells coexpressing WT $+\mathrm{F} 640 \mathrm{~V}$ were significantly reduced compared with cells expressing WT $(P<0.001)$. $\mathrm{I}_{\text {tail }}$ densities of WT+F640V channels increased with rising temperatures $\left(12 \pm 2,25 \pm 4\right.$, and $28 \pm 4 \mathrm{pA} / \mathrm{pF}$ at $23^{\circ} \mathrm{C}, 35^{\circ} \mathrm{C}$, and $40^{\circ} \mathrm{C}$, respectively; $P<0.005)$. However, compared with WT, the temperaturedependent increase of $\mathrm{I}_{\text {tail }}$ density was significantly smaller for the WT + F640V channels $\left(13 \pm 2\right.$ and $3 \pm 1 \mathrm{pA} / \mathrm{pF}$ from $23^{\circ} \mathrm{C}$ to $35^{\circ} \mathrm{C}$ and $35^{\circ} \mathrm{C}$ to $40^{\circ} \mathrm{C}$, respectively; $\left.\mathrm{P}<0.001\right)$. Similar to WT $+\mathrm{A} 558 \mathrm{P}$ channels, this led to a larger difference in $\mathrm{I}_{\text {tail }}$ density between WT and WT+F640V channels at higher temperatures (Figure 5C).

Activation. Figure 6A shows the voltage-dependence of activation for WT and WT+A558P channels. To study activation, cells were depolarized from $-80 \mathrm{mV}$ to $60 \mathrm{mV}$ in $10 \mathrm{mV}$ increments for $5 \mathrm{sec}$ onds (prepulse), followed by a test pulse to $-50 \mathrm{mV}$ for 5 seconds to measure $\mathrm{I}_{\text {tail }}$ (Figure $6 \mathrm{~A}$, inset). $\mathrm{I}_{\text {tail }}$ values were normalized to maximum value, averaged, and plotted as a function of the prepulse voltage. Corresponding current-voltage curves were fitted to a Boltzmann equation to determine the membrane potential of half-maximal activation $\left(\mathrm{V}_{1 / 2}\right)$ and the slope factors of activation. Raising the temperature shifted the $\mathrm{V}_{1 / 2}$ toward more negative potentials in equal measures in both cell groups $(-18 \pm 3,-32 \pm 3$, and $-38 \pm 4 \mathrm{mV}$ for $\mathrm{WT}$ at $23^{\circ} \mathrm{C}, 35^{\circ} \mathrm{C}$, and $40^{\circ} \mathrm{C}$ versus $-19 \pm 2$, $-30 \pm 2$, and $-35 \pm 4 \mathrm{mV}$ for $\mathrm{WT}+\mathrm{A} 558 \mathrm{P}$ at $23^{\circ} \mathrm{C}, 35^{\circ} \mathrm{C}$, and $40^{\circ} \mathrm{C}$, respectively; $P<0.001$ ) but did not affect the slope factor values $\left(7.1 \pm 0.4,6.5 \pm 0.5\right.$, and $7.0 \pm 0.7$ for WT at $23^{\circ} \mathrm{C}, 35^{\circ} \mathrm{C}$, and $40^{\circ} \mathrm{C}$ versus $7.7 \pm 0.2,7.2 \pm 0.3$, and $7.4 \pm 0.3$ for WT $+A 558 \mathrm{P}$ at $23^{\circ} \mathrm{C}$, $35^{\circ} \mathrm{C}$, and $40^{\circ} \mathrm{C}$, respectively). These data indicate earlier activation of both WT and WT+A558P channels at higher temperatures. At each temperature, there was no difference in $V_{1 / 2}$ or slope factor between WT and WT+A558P channels.

Inactivation. Figure 6B shows the voltage-dependence of inactivation for WT and WT+A558P channels. To study inactivation, cells were depolarized from $-80 \mathrm{mV}$ to $50 \mathrm{mV}$ for 1.5 seconds, 
A

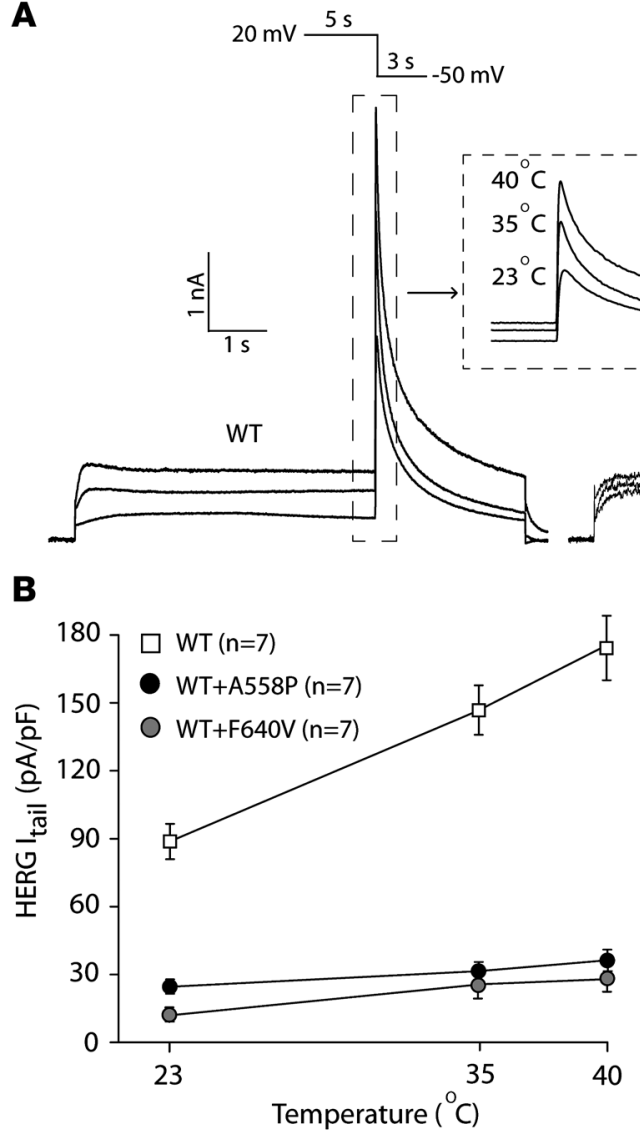

Figure 5

Effect of temperature on current density. (A) Representative $\mathrm{I}_{\text {tail }}$ for WT and WT+A558P mutant channels first measured at $23^{\circ} \mathrm{C}$, repeated at $35^{\circ} \mathrm{C}$, and then at $40^{\circ} \mathrm{C}$ for each cell. Scale bars for representative $I_{\text {tail }}: 1 \mathrm{nA}$, $1 \mathrm{~s}$; scale bars for enlarged WT $I_{\text {tail: }} 2 \mathrm{nA}, 0.25 \mathrm{~s}$; scale bars for enlarged WT+A558P I tail: $0.5 \mathrm{nA}$, $0.25 \mathrm{~s}$. I tail $_{\text {tal }}$ increased for both channels with rising temperature. (B) Average I tail densities at $23^{\circ} \mathrm{C}, 35^{\circ} \mathrm{C}$, and $40^{\circ} \mathrm{C}$. Compared with $\mathrm{WT}$, the temperature-dependent increase of $I_{\text {tail }}$ density was significantly smaller for WT+A558P and WT+F640V channels. Cells were cultured at $37^{\circ} \mathrm{C}$. (C) Average differences between WT and WT+A558P or $\mathrm{WT}+\mathrm{F} 640 \mathrm{~V} \mathrm{I}_{\text {tail }}$ densities at $23^{\circ} \mathrm{C}$, $35^{\circ} \mathrm{C}$, and $40^{\circ} \mathrm{C}$. Differences in $I_{\text {tail }}$ densities increased with rising temperature. ${ }^{*} P<0.001$ compared with $23^{\circ} \mathrm{C}$; ${ }^{*} P<0.001$ compared with $35^{\circ} \mathrm{C}$. followed by hyperpolarization to $-100 \mathrm{mV}$ for 5 milliseconds, and next stepped to test pulses between -20 and $60 \mathrm{mV}$ in $10 \mathrm{mV}$ decrements for 1.5 seconds (Figure 6B, inset). Time constants of inactivation were calculated by fitting the decay of $\mathrm{I}_{\text {tail }}$ during the test pulses to a single exponential function. The data indicate that inactivation is accelerated (a) at more depolarized membrane potentials; (b) at higher temperatures; and (c) in the presence of A558P ( $P<0.05$ for comparison at all tested voltages). Accelerated inactivation suggests a further reduction of HERG current in the WT+A558P channels, due to faster closing of the channels after activation.

Recovery from inactivation. Figure 6C shows the voltage-dependence of recovery from inactivation. To study recovery from inactivation, cells were depolarized from $-80 \mathrm{mV}$ to $50 \mathrm{mV}$ for 1.5 seconds, followed by hyperpolarizing test pulses between -100 and $-20 \mathrm{mV}$ in $10 \mathrm{mV}$ increments for 3 seconds (Figure 6C, inset). The initial phase of $\mathrm{I}_{\text {tail }}$ during the test pulses reflects recovery from inactivation and was fitted to a single exponential function. Due to the fast biophysical properties of $\mathrm{I}_{\text {tail }}$ at $35^{\circ} \mathrm{C}$ and $40^{\circ} \mathrm{C}$, only time constants for pulses between -70 and $-20 \mathrm{mV}$ could be analyzed. At $23^{\circ} \mathrm{C}$, WT + A558P channels recovered significantly faster at -30 and $-20 \mathrm{mV}$ compared with WT (time constants, $8.1 \pm 0.4 \mathrm{~ms}$ and $7.9 \pm 0.4 \mathrm{~ms}$ for $\mathrm{WT}$ at -30 and $-20 \mathrm{mV}$ versus $6.9 \pm 0.2 \mathrm{~ms}$ and $6.6 \pm 0.3 \mathrm{~ms}$ for $\mathrm{WT}+\mathrm{A} 558 \mathrm{P} ; \mathrm{P}<0.01)$. At $35^{\circ} \mathrm{C}$, there was no difference between the cell groups. At $40^{\circ} \mathrm{C}$, recovery of WT + A558P channels became slower at -70 and $-60 \mathrm{mV}$ compared with WT (time constants, $1.8 \pm 0.2 \mathrm{~ms}$ and $2.5 \pm 0.3 \mathrm{~ms}$ for $\mathrm{WT}$ at -70 and $-60 \mathrm{mV}$ vs. $2.7 \pm 0.2,3.0 \pm 0.2 \mathrm{~ms}$ for $\mathrm{WT}+\mathrm{A} 558 \mathrm{P}$;
$P<0.01)$. Although the differences are small, these data suggest an abnormal response of recovery rates to changing temperature in the WT+A558P channels.

Deactivation. Figure 6D shows the voltage dependence of the fast and slow time constants of deactivation. The same voltageclamp protocol as for recovery from inactivation was used, except that the decay of $\mathrm{I}_{\text {tail }}$ was fit to a double-exponential function to obtain fast and slow time constants of deactivation. In WT and WT + A558P channels, deactivation time constants decreased at more negative membrane potentials. Increasing temperature accelerated the fast and slow time constants, but the effect was small. At each temperature, the presence of A558P did not alter the response of the WT channels.

\section{Discussion}

Fever has not been recognized as a trigger of cardiac events in LQTS. In Brugada syndrome (BrS), fever is an established trigger of cardiac events (20-22). BrS is another inherited cardiac disease, leading to ventricular tachycardia, VF, and sudden death. In a subset of patients, BrS is linked to mutations in SCN5A, the gene that encodes the cardiac $\mathrm{Na}^{+}$channel, which carries depolarizing $\mathrm{Na}^{+}$current $\left(\mathrm{I}_{\mathrm{Na}}\right)$ during the cardiac action potential. BrS-related mutations in $S C N 5 A$ reduce $\mathrm{I}_{\mathrm{Na}}$, thereby impairing cardiac depolarization (23). A possible biophysical basis of the increased risk of arrhythmia during fever was revealed by patch-clamp studies of BrS-linked SCN5A mutations conducted at near-physiologic temperatures. These studies showed temperature-sensitive biophysical properties of mutant $\mathrm{Na}^{+}$channels that reduced $\mathrm{I}_{\mathrm{Na}}$ compared 
A

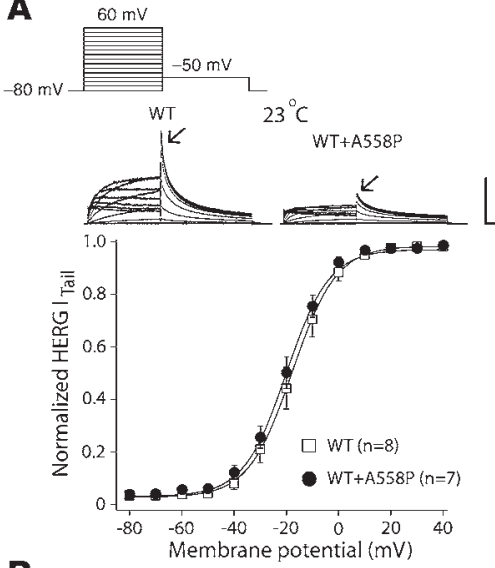

B

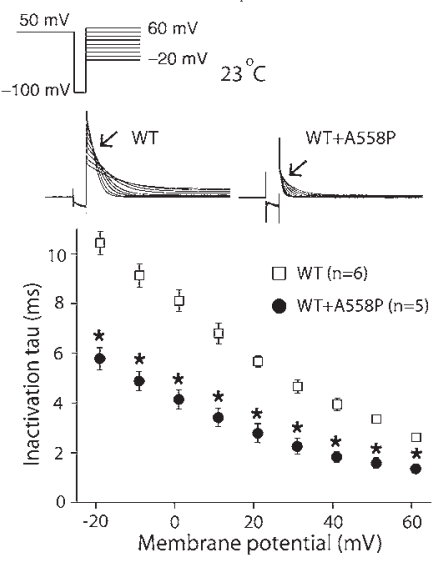

C
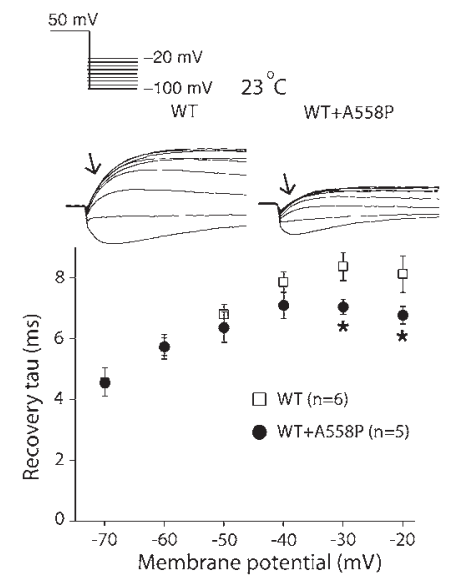

D
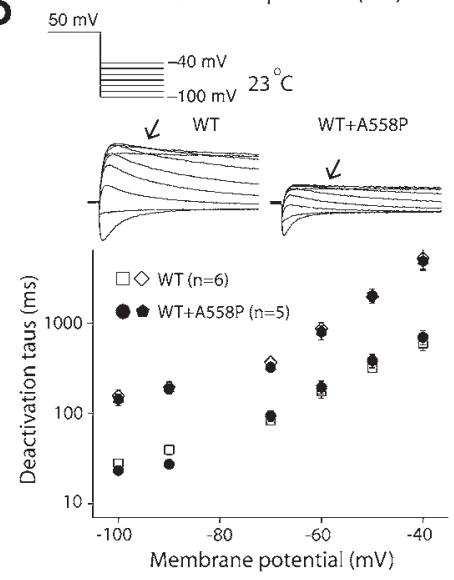
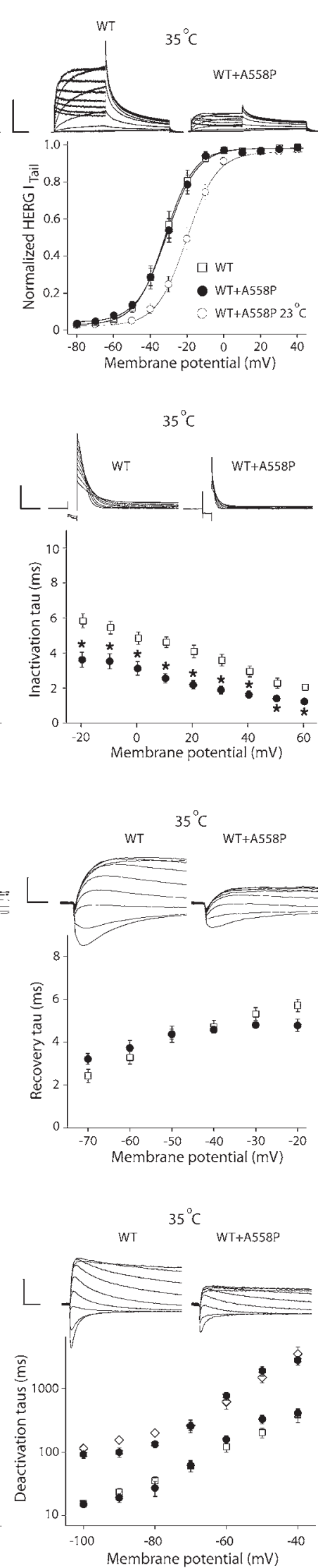

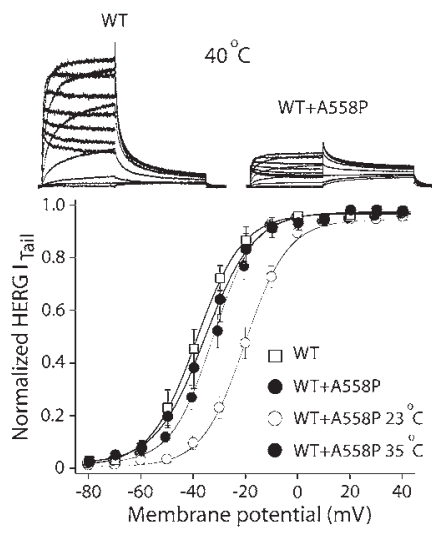

$40^{\circ} \mathrm{C}$
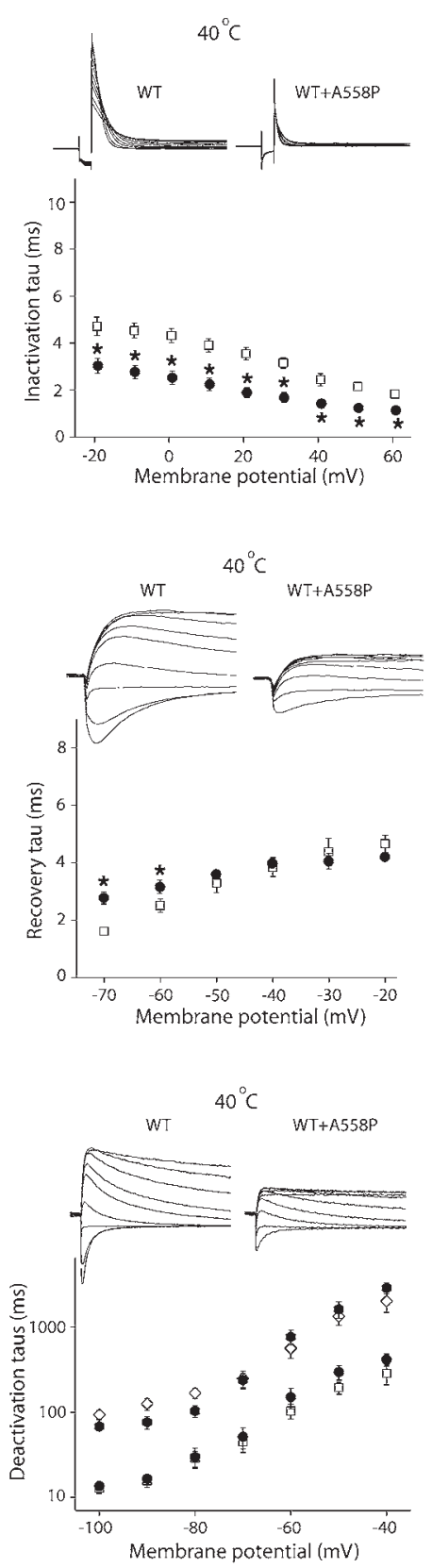

Figure 6

Effect of temperature on gating properties: activation, inactivation, recovery from inactivation, and deactivation. For each parameter (portion of) representative current traces of WT and $\mathrm{WT}+\mathrm{A} 558 \mathrm{P}$ channels at $23^{\circ} \mathrm{C}, 35^{\circ} \mathrm{C}$, and $40^{\circ} \mathrm{C}$ within the same cell are shown. Voltage-clamp protocols are shown in the insets. Cells were cultured at $37^{\circ} \mathrm{C}$. (A) For activation, the scale bars for representative current traces: $1 \mathrm{nA}$, $1 \mathrm{~s}$. Arrows indicate $\mathrm{I}_{\text {tail }}$. The mean Itail normalized to maximum value are plotted as a function of the prepulse voltage. The solid lines represent Boltzmann equation fits. (B) For inactivation, the scale bars for representative current traces: $4 \mathrm{nA}$, $10 \mathrm{~ms}$. Arrows indicate channel inactivation. Mean time constants of inactivation are plotted as a function of test voltage. (C) For recovery from inactivation, the scale for representative current traces: $1 \mathrm{nA}, 10 \mathrm{~ms}$. Arrows indicate channel recovery. Mean time constants of recovery from inactivation are plotted as a function of test voltage. (D) For deactivation, the scale bars for representative current traces: $1 \mathrm{nA}$, $50 \mathrm{~ms}$. Arrows indicate channel deactivation. Mean time constants of deactivation are plotted as a function of test voltage. ${ }^{*} P<0.05$ compared with WT (ANOVA). See Results for details. 
with studies conducted at room temperature $(24,25)$. Thus, the reduction of $\mathrm{I}_{\mathrm{Na}}$ at febrile temperatures is thought to increase arrhythmogenicity in BrS patients.

In this study, we described 2 related LQT-2 patients with the A558P HERG missense mutation who experienced syncope, TdP, and VF during recurrent fever. ECG analysis during fever and following resumption of normothermia revealed QTc lengthening with rising body temperature in both patients. In healthy subjects, Karjalainen and Viitasalo showed that the QT interval significantly shortened during fever (26). Accordingly, we observed a significant decrease of QTc duration with rising body temperature in control patients without LQTS. Indeed, experiments in canine cardiac ventricular preparations have reported action potential shortening at $40^{\circ} \mathrm{C}(27)$, indicating faster cardiac repolarization at higher temperatures and providing support for the clinical observations. Based on this sharp contrast in QTc response to rising body temperature between the 2 LQT- 2 patients and control subjects, we hypothesized that the A558P mutation affects HERG channel function in a temperature-dependent manner. To test this hypothesis, we studied the effect of temperature on heterologously expressed WT and A558P containing mutant HERG channels. The key new findings are (a) A558P homomeric channels showed a severe trafficking-deficient phenotype; (b) the trafficking of A558P homomeric channels was not temperature-dependent (not correctable by culture at $27^{\circ} \mathrm{C}$ or $40^{\circ} \mathrm{C}$ ); (c) the deficient trafficking could only be minimally corrected by incubation with E-4031; (d) coexpression of WT + A558P HERG revealed that the mutation imposes a dominant-negative effect; (e) the normal increase in WT HERG current density at higher temperatures was reduced by coexpression of A558P subunits; and (f) A558P coexpressed with WT selectively accelerated the inactivation rates. A558P had little or no effect on HERG channel activation, recovery from inactivation, or deactivation. Our findings are in agreement with previous studies of WT HERG currents measured at room temperature and near-physiologic temperature $(16,28)$. We believe this is the first report studying WT and mutant HERG currents at $40^{\circ} \mathrm{C}$.

HERG mutations are thought to decrease $\mathrm{I}_{\mathrm{Kr}}$ to cause LQT-2, mostly by deficient trafficking of mutant channel proteins to the cell membrane (5). The coassembly of mutant subunits with WT subunits also can lead to the formation of dysfunctional channel tetramers in the cell membrane (2). While abnormal trafficking results in decreased number of functional HERG channels in the cell membrane, the formation of dysfunctional tetramers results in the presence of channels that may have altered gating or ion permeability properties (7). Ion channel gating is a complex, multistep process, involving multiple different conformational states of the channel protein. The rate of the gating process is temperature sensitive, and it is increased at higher temperatures (28). The presence of mutant subunits in the tetrameric HERG channel may alter the normal temperature sensitivity of gating. In the present study, we coexpressed WT+A558P HERG in HEK293 cells. Although we did not selectively label the individual subunits to assess coassembly biochemically (29), the marked reduction in current density, along with the selective acceleration of inactivation, provides strong evidence for coassembly of WT and A558P subunits. Compared to WT channels, HERG current density in coassembled WT + A558P channels was reduced $77 \%$ at $35^{\circ} \mathrm{C}$. In the computer simulation model of the ventricular action potential developed by Luo and Rudy, a $75 \%$ reduction in $\mathrm{I}_{\mathrm{Kr}}$ led to an approximately $17 \%$ increase in the action potential duration at physiological temperatures (30).
Furthermore, although both WT and WT+A558P current densities increased with rising temperatures, for WT+A558P channels this increase was small compared with that found with WT channels. Since current densities of the depolarizing cardiac $\mathrm{Na}^{+}$and L-type $\mathrm{Ca}^{2+}$ currents also are significantly greater at higher temperatures $(24,25,31)$, we speculate that failure of repolarizing WT + A558P HERG currents to adequately increase at higher temperatures alters the balance between depolarizing and repolarizing currents in favor of depolarization. This will lead to a further delay in cardiac repolarization during fever. The increased rate of channel inactivation would also favor a further reduction in WT+A558P HERG current to further delay repolarization.

The importance of $\mathrm{I}_{\mathrm{Kr}}$ for maintaining an adequate balance between depolarizing and repolarization during hyperthermia has been previously studied in isolated canine left ventricular $\mathrm{M}$ cells and Purkinje fiber preparations (32). When HERG channels were blocked by pretreatment with E-4031, elevation of recording temperature into the fever range (up to $40^{\circ} \mathrm{C}$ ) induced prolongation of action potential duration and triggered early afterdepolarizations (EADs). EADs are thought to be responsible for the initiation of TdP (33). Remarkably, EADs were not seen at temperatures lower than $33^{\circ} \mathrm{C}$. Although this study did not investigate whether HERG channel block by E-4031 was more potent at higher temperatures, other studies did not find a temperature-dependent change in the potency of E-4031 block of HERG channels $(34,35)$. These data illustrate that the functional implications of $\mathrm{I}_{\mathrm{Kr}}$ reduction are greater during hyperthermia and support our postulate that failure of mutant HERG current to adequately increase at higher temperatures delays cardiac repolarization.

Finally, the increase in current density with rising temperatures was also small for the WT+F640V channels, leading to a larger difference in current density at higher temperatures compared with WT channels. We previously showed that most LQT-2-linked HERG channel mutations, including F640V, have a traffickingdeficient phenotype and impose a dominant-negative effect on WT protein trafficking (5). Thus, although fever-induced QTc lengthening and arrhythmias for F640V or other HERG mutations are not yet reported, our experimental data suggest that a temperature-dependent phenotype may be expected for other LQT-2-linked mutations.

In summary, we described fever-induced QT interval prolongation, TdP, and VF in 2 LQT-2 patients with the A558P mutation. Biochemical and biophysical analysis revealed that A558P is trafficking deficient, that it coassembles with WT subunits to cause dominant-negative behavior, and that its current density fails to increase with increasing temperature to the same extent as WT channels. Although the effects of fever on the heart are complex, our findings, together with previous experimental observations in LQTS, provide a potential mechanism that may explain the QTc lengthening with rising body temperature in our LQT-2 patients. We believe our findings demonstrate a novel arrhythmogenic mechanism for the A558P mutation at febrile temperatures, which possibly has mechanistic implications for other LQT-2-linked HERG mutations. Clearly, the role of fever in LQT-2 patients merits further investigation.

\section{Methods}

This study was approved by the local ethics committee of the Academic Medical Centre in Amsterdam, and the patients gave informed consent for participation. The investigation conforms to the principles outlined in the Declaration of Helsinki. 
ECG analysis. ECG tracings were enlarged to facilitate manual analysis. QT duration (lead $V_{5}$ ) was corrected for heart rate using Bazett's formula $(Q T c=Q T / \sqrt{ } R R$, where $R R$ is the interval, measured in seconds, from the onset of 1 QRS complex to the onset of the following QRS complex). The control group of patients without LQTS was admitted at the Academic Medical Centre for the treatment of a febrile episode. Two patients had pneumonia, 2 had cholangitis, 1 had toxicoderma due to omeprazole use, 1 had colitis, 1 had central venous catheter infection, and in 2 patients no cause of fever was found. Control patients had no history of cardiac disease, used no medications known to prolong the QT interval, had normal electrolytes, and had a normal cardiothoracic ratio on chest roentgenograms.

Site-directed mutagenesis. To generate the A558P and the F640V constructs, the appropriate nucleotide change (G1672C or A1918T) was engineered into WT HERG cDNA, which was then expressed in the PCDNA3 vector (Invitrogen) (5). The mutant constructs were sequenced to verify the presence of the $\mathrm{G} 1672 \mathrm{C}$ or $\mathrm{A} 1918 \mathrm{~T}$ substitution and to ensure the absence of other nucleotide changes.

Cell culture and transfection. HEK293 cells were cultured in Minimal Essential Medium (MEM) supplemented with 10\% fetal bovine serum, penicillin, streptomycin, and nonessential amino acids. Transient transfections were

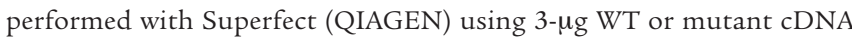
(homomeric channels) or 1.5- $\mu \mathrm{g}$ WT and $1.5-\mu \mathrm{g}$ mutant cDNA (heteromeric channels). In some experiments, cells were transfected with $1.5-\mu \mathrm{g}$ WT cDNA and 1.5- $\mu \mathrm{g}$ pCDNA3 vector. Green fluorescence protein was cotransfected to identify transfected cells under epifluorescent microscopy. The cells were incubated in $5 \% \mathrm{CO}_{2}$ at $37^{\circ} \mathrm{C}$, unless noted otherwise. In some experiments, $10-\mu \mathrm{mol} / 1 \mathrm{E}-4031$ (Sigma-Aldrich; $10-\mathrm{mmol} / 1$ stock dissolved in distilled water) was added to the cell culture media 24 hours before experiments and washed out for 1-2 hours prior to the study. All experiments were performed 48 hours after transfection.

Western blot. Whole-cell lysates were generated by treating cell cultures of similar confluency with $1 \%$ Nonidet P-40 buffer. Equal protein amounts were measured using a Bio-Rad protein assay and mixed with SDS-PAGE sample buffer containing $5-\mathrm{mmol} / 1$ dithiothreitol, before heating for 15 minutes at $60^{\circ} \mathrm{C}$. The proteins were then subjected to $7.5 \%$ SDS-polyacrylamide gel electrophoresis and electrophoretically transferred onto nitrocellulose membranes. The nitrocellulose membranes were incubated overnight at room temperature with a HERG C-terminal antibody and visualized using an ECL detection kit (Amersham) (16).

Electrophysiology. HERG currents were measured using the whole-cell configuration of the patch-clamp technique with an Axopatch-200 amplifier (Axon Instruments). Pipettes were pulled with a micropipette puller (Sutter Instruments). They had a tip resistance of 3-4 M $\Omega$ when filled with pipette solution, which contained $130 \mathrm{mM} \mathrm{KCl}, 1 \mathrm{mM} \mathrm{MgCl}_{2}, 5 \mathrm{mM}$ EGTA, $5 \mathrm{mM}$ MgATP, and $10 \mathrm{mM}$ HEPES ( $\mathrm{pH} 7.2$ with $\mathrm{KOH}$ ). The extracellular solution contained $137 \mathrm{mM} \mathrm{NaCl}, 4 \mathrm{mM} \mathrm{KCl}, 1.8 \mathrm{mM} \mathrm{CaCl}, 1 \mathrm{mM} \mathrm{MgCl}$, $10 \mathrm{mM}$ glucose, and $10 \mathrm{mM}$ HEPES ( $\mathrm{pH} 7.4$ with $\mathrm{NaOH}$ ). Currents were filtered at $5 \mathrm{kHz}$ and digitized at $10 \mathrm{kHz}$. The holding potential in all experiments was $-80 \mathrm{mV}$. The voltage-clamp protocols were generated using the pCLAMP 8.0 software (Axon Instruments) and are described in the Results and Figures.
We studied the biophysical properties of WT and mutant HERG currents at $23^{\circ} \mathrm{C}, 35^{\circ} \mathrm{C}$, and $40^{\circ} \mathrm{C}$. Currents were first measured at $23^{\circ} \mathrm{C}$, and measurements were then repeated at $35^{\circ} \mathrm{C}$ and $40^{\circ} \mathrm{C}$ for the same cell. The recording temperature in the cell perfusion chamber was directly monitored, and each temperature increase was achieved within 30 seconds using a $\mathrm{TC}^{2}$ temperature controller (Cell MicroControls). Current densities were obtained by normalizing current amplitudes to membrane capacitance $(\mathrm{Cm})$. $\mathrm{Cm}$ did not change at higher temperatures $(14.0 \pm 1.3,15.0 \pm 1.2$, and $14.3 \pm 1.8$ at $23^{\circ} \mathrm{C}, 35^{\circ} \mathrm{C}$, and $40^{\circ} \mathrm{C}$, respectively). Criteria for successful experiments were (a) stable seal resistance of greater than $1 \mathrm{G} \Omega$, (b) $\mathrm{Cm}$ and series resistance compensation greater than or equal to $80 \%$, and (c) less than $5 \%$ rundown. Each cell was used to measure a single gating process (e.g., activation, inactivation, etc.). Measurements for all temperatures were completed within 10 minutes after obtaining intracellular access.

Statistics. Values are expressed as mean \pm SEM. Linear regression and covariance analysis were used to assess the relation between QTc and body temperature in LQT-2 patients and the control group of patients without LQTS. The slopes of the linear fits were evaluated for differences from 0 and between the fits. Covariance analysis was used to determine common slopes for LQT-2 and control patients, accounting for the within patient correlation. Variance around the common slope was tested for significant differences in slope and location of the regression per group. For in vitro experiments, statistical analysis was carried out using (a) unpaired $t$ test for comparisons of current densities between 2 different groups; (b) 1-way ANOVA repeated measures for comparisons of current densities within 1 group between different recording temperatures; or (c) 2 -way ANOVA repeated measures for comparisons of gating processes. $P<0.05$ (2-tailed) was considered as statistically significant.

\section{Acknowledgments}

This study was supported by the Netherlands Heart Foundation grant NHS 2003T302 (Arthur A.M. Wilde), the Netherlands Organisation for Scientific Research grant NWO 902-16-193 (Arthur A.M. Wilde), the National Heart, Lung, and Blood Institute grant R01 HL60723 (Craig T. January), the Royal Netherlands Academy of Arts and Sciences grant KNAW (Hanno L. Tan), and the Netherlands Organisation for Scientific Research grant NWO ZonMW-VICI 918-86-616 (Hanno L. Tan).

Received for publication February 14, 2008, and accepted in revised form May 7, 2008.

Address correspondence to: Arthur A.M. Wilde, Department of Cardiology, Academic Medical Centre, Meibergdreef 9, 1105 AZ Amsterdam, The Netherlands. Phone: 31-20-5662904; Fax: 31-206971385; E-mail: a.a.wilde@amc.uva.nl. Or to: Craig T. January, University of Wisconsin Hospital and Clinics, Division of Cardiovascular Medicine, Room H6/354 CSC, 600 Highland Avenue, Madison, Wisconsin 53792, USA. Phone: (608) 263-4856; Fax: (608) 263-0405; E-mail: ctj@medicine.wisc.edu.
1. Roden, D.M. 2008. Clinical practice. Long QT syndrome. N. Engl. J. Med. 358:169-176.

2. January, C.T., Gong, Q., and Zhou, Z. 2000. Long QT syndrome: cellular basis and arrhythmia mechanism in LQT2. J. Cardiovasc. Electrophysiol. 11:1413-1418.

3. Sanguinetti, M.C., Curran, M.E., Spector, P.S., and Keating, M.T. 1996. Spectrum of HERG K ${ }^{+}$channel dysfunction in an inherited cardiac arrhythmia. Proc. Natl. Acad. Sci. U. S. A. 93:2208-2212.

4. MacKinnon, R. 1991. Determination of the subunit stoichiometry of a voltage-activated potassium channel. Nature. 350:232-235.

5. Anderson, C.L., et al. 2006. Most LQT2 mutations reduce Kv11.1 (hERG) current by a class 2 (trafficking-deficient) mechanism. Circulation. 113:365-373.

6. Ficker, E., et al. 2000. Retention in the endoplasmic reticulum as a mechanism of dominant-negative current suppression in human long QT syndrome. J. Mol. Cell. Cardiol. 32:2327-2337.

7. Delisle, B.P., Anson, B.D., Rajamani, S., and January, C.T. 2004. Biology of cardiac arrhythmias: ion channel protein trafficking. Circ. Res.
94:1418-1428.

8. Tan, H.L., Hou, C.J., Lauer, M.R., and Sung, R.J. 1995. Electrophysiologic mechanisms of the long QT interval syndromes and torsade de pointes. Ann. Intern. Med. 122:701-714.

9. Schwartz, P.J., et al. 2001. Genotype-phenotype correlation in the long QT syndrome: gene-specific triggers for life-threatening arrhythmias. Circulation. 103:89-95.

10. Wilde, A.A., et al. 1999. Auditory stimuli as a trigger for arrhythmic events differentiate HERG-related (LQTS2) patients from KvLQT1-related patients 
(LQTS1). J. Am. Coll. Cardiol. 33:327-332.

11. Mackowiak, P.A. 1998. Concepts of fever. Arch. Intern. Med. 158:1870-1881.

12. Jongbloed, R.J., et al. 1999. Novel KCNQ1 and HERG missense mutations in Dutch long QT families. Hum. Mutat. 13:301-310.

13. Tan, H.L., Alings, M., Van Olden, R.W., and Wilde, A.A. 1999. Long-term (subacute) potassium treatment in congenital HERG-related long QT syndrome (LQTS2). J. Cardiovasc. Electrophysiol. 10:229-233.

14. Gaita, F., et al. 2003. Short QT Syndrome: a familial cause of sudden death. Circulation. 108:965-970.

15. Rajamani, S., et al. 2006. Specific serine proteases selectively damage KCNH2 (hERG1) potassium channels and $\mathrm{I}_{\mathrm{Kr}}$. Am. J. Physiol. Heart Circ. Physiol. 290:H1278-H1288.

16. Zhou, Z., et al. 1998. Properties of HERG channels stably expressed in HEK-293 cells studied at physiological temperature. Biophys J. 74:230-241.

17. Ficker, E., Dennis, A.T., Wang, L., and Brown, A.M. 2003. Role of the cytosolic chaperones Hsp70 and Hsp90 in maturation of the cardiac potassium channel HERG. Circ. Res. 92:E87-E100.

18. Guo, J., et al. 2007. Identification of $\mathrm{I}_{\mathrm{Kr}}$ and its trafficking disruption induced by probucol in cultured neonatal rat cardiomyocytes. J. Pharmacol. Exp. Ther. 321:911-920.

19. Tester, D.J., Will, M.L., Haglund, C.M., and Ackerman, M.J. 2005. Compendium of cardiac channel mutations in 541 consecutive unrelated patients referred for long QT syndrome genetic testing.
Heart Rhythm. 2:507-517.

20. Antzelevitch, C., and Brugada, R. 2002. Fever and Brugada syndrome. Pacing Clin. Electrophysiol. 25:1537-1539.

21. Keller, D.I., et al. 2006. A novel SCN5A mutation, F1344S, identified in a patient with Brugada syndrome and fever-induced ventricular fibrillation. Cardiovasc Res. 70:521-529.

22. Porres, J.M., et al. 2002. Fever unmasking the Brugada syndrome. Pacing Clin. Electrophysiol. 25:1646-1648.

23. Antzelevitch, C., et al. 2005. Brugada syndrome: report of the second consensus conference. Heart Rhythm. 2:429-440.

24. Dumaine, R., et al. 1999. Ionic mechanisms responsible for the electrocardiographic phenotype of the Brugada syndrome are temperature dependent. Circ. Res. 85:803-809.

25. Amin, A.S., Verkerk, A.O., Bhuiyan, Z.A., Wilde, A.A., and Tan, H.L. 2005. Novel Brugada syndrome-causing mutation in ion-conducting pore of cardiac $\mathrm{Na}^{+}$channel does not affect ion selectivity properties. Acta Physiol. Scand. 185:291-301.

26. Karjalainen, J., and Viitasalo, M. 1986. Fever and cardiac rhythm. Arch. Intern. Med. 146:1169-1171.

27. Morita, H., Zipes, D.P., Morita, S.T., and Wu, J. 2007. Temperature modulation of ventricular arrhythmogenicity in a canine tissue model of Brugada syndrome. Heart Rhythm. 2:188-197.

28. Vandenberg, J., et al. 2006. Temperature dependence of human ether-a-go-go-related gene $\mathrm{K}^{+}$currents. Am. J. Physiol. Cell Physiol. 291:C165-C175.

29. Gong, Q., Anderson, C.L.,January, C.T., and Zhou, Z.
2004. Pharmacological rescue of trafficking defective HERG channels formed by coassembly of wildtype and long QT mutant N470D subunits. Am. J. Physiol. Heart Circ. Physiol. 287:H652-H658.

30. Zeng, J., Laurita, K.R., Rosenbaum, D.S., and Rudy, Y. 1995. Two components of the delayed rectifier $\mathrm{K}+$ current in ventricular myocytes of the guinea pig type. Theoretical formulation and their role in repolarization. Circ. Res. 77:140-152.

31. Yamaoka, K., Yuki, T., Kawase, K., Munemori, M., and Seyama, I. 2002. Temperature-sensitive intracellular $\mathrm{Mg}^{2+}$ block of L-type $\mathrm{Ca}^{2+}$ channels in cardiac myocytes. Am. J. Physiol. Heart Circ. Physiol. 282:H1092-H1101.

32. Burashnikov, A., and Antzelevitch, C. 1998. Temperature-dependence of early afterdepolarization activity in canine left ventricular $\mathrm{M}$ cell and Purkinje fiber preparations [abstract]. Pacing Clin. Electrophysiol. 21:II-857.

33. Yan, G.X., et al. 2001. Phase 2 early afterdepolarization as a trigger of polymorphic ventricular tachycardia in acquired long-QT syndrome: direct evidence from intracellular recordings in the intact left ventricular wall. Circulation. 103:2851-2856.

34. Yao, J.A., et al. 2005. Estimation of potency of HERG channel blockers: impact of voltage protocol and temperature. J. Pharmacol. Toxicol. Methods. 52:146-153.

35. Kirsch, G.E., et al. 2004. Variability in the measurement of hERG potassium channel inhibition: effects of temperature and stimulus pattern. J. Pharmacol. Toxicol. Methods. 50:93-101. 